$\mathrm{Oz}$

$1-1-2018$

\title{
The Joys and Challenges of Stickworking
}

Patrick Dougherty

Follow this and additional works at: https://newprairiepress.org/oz

Part of the Architecture Commons

(c) $(1) \Theta$

This work is licensed under a Creative Commons Attribution-Noncommercial-No Derivative Works 4.0 License.

\section{Recommended Citation}

Dougherty, Patrick (2018) "The Joys and Challenges of Stickworking," Oz: Vol. 40. https://doi.org/10.4148/ 2378-5853.1580

This Article is brought to you for free and open access by New Prairie Press. It has been accepted for inclusion in Oz by an authorized administrator of New Prairie Press. For more information, please contact cads@k-state.edu. 
The Joys and Challenges of Stickworking

\author{
Patrick Dougherty
}

After thirty years of springing largescale sapling sculptures into unlikely places, it has become easier for me to distill some of the constants that characterize my work. In that regard, the work is temporary, uses entanglement as a simple fastener, employs a drawing style akin to works on paper, always needs a sponsor, capitalizes on volunteer help, and is open to the public during the building phase. Further, the work has always sought to find reciprocity with the sculpture site and, most importantly, to enliven the imagination of the viewers.

During my sculptural infancy in the early 1980s, I deduced from Robert Smithson and his Spiral Jetty that it was okay for sculptors to change the rules and escape the confines of studio or gallery. Subsequently, I gravitated toward ephemeral work-work that allowed my sculptures to play out the natural life cycle of branches and saplings. (Generally a saplings sculpture has one great year and one "pretty good" year before it is taken down.) I also aspired to a working style that seems authentic and credible. Given my atavistic tendencies, I decried all regular fasteners and relied instead on a sapling's propensity to snag on anything it touches. Using snagging and intertwining as a method of joining helped with the illusion that the sculptures were not man-made but the results of natural forces.

In those early formative days, I developed the impression that sculpture painting. Loose talk suggested that painting required a continuous response to the surface that left it brimming with personal and emotional content. I wanted to build sculptures that required the same interplay. Perhaps in an attempt to fuse painting and sculpture, I began to think of the saplings along my driveway, not as brush from the woods, but as groups of lines with which to draw, and I hoped that the constant reaction between the hand as pencil and the developing surface would indeed produce a more personal and forceful work.

As my learning curve improved, I encouraged sponsoring organizations to become partners in the production of their sculpture. They needed to raise the funds, but it was also important to use their goodwill and leverage in the community to organize all the logistical needs; that is, finding a gathering site and obtaining permission, organizing volunteers to assist in the harvest and build, and helping to identify and problem solve a promising sculpture site. Thus, my work has not been a direct fontal assault on public space. Rather, this partnership has often allowed the sculpture to creep in the backdoor of public consciousness. As time goes on, the work often finds the limelight and community appeal beyond the organization that sponsored it.

My job as a sculptor is to stir the viewer's imagination, and one aspect of that effort is actually to understand the viewer. In that regard, I maintain

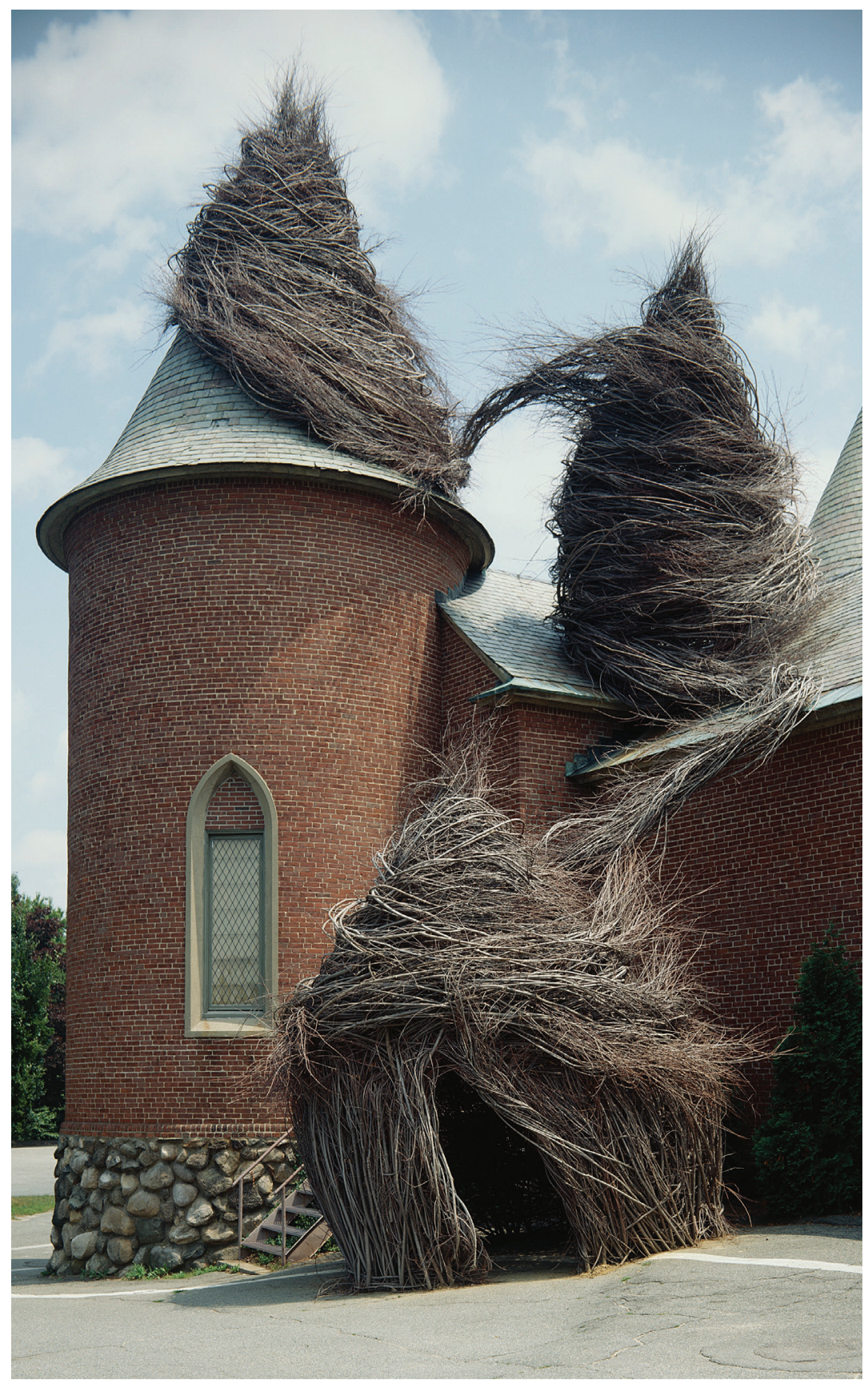

Spinoffs (1990), deCordova Museum and Sculpture Park, Lincoln, Massachusetts. Photo: George Vasquez 


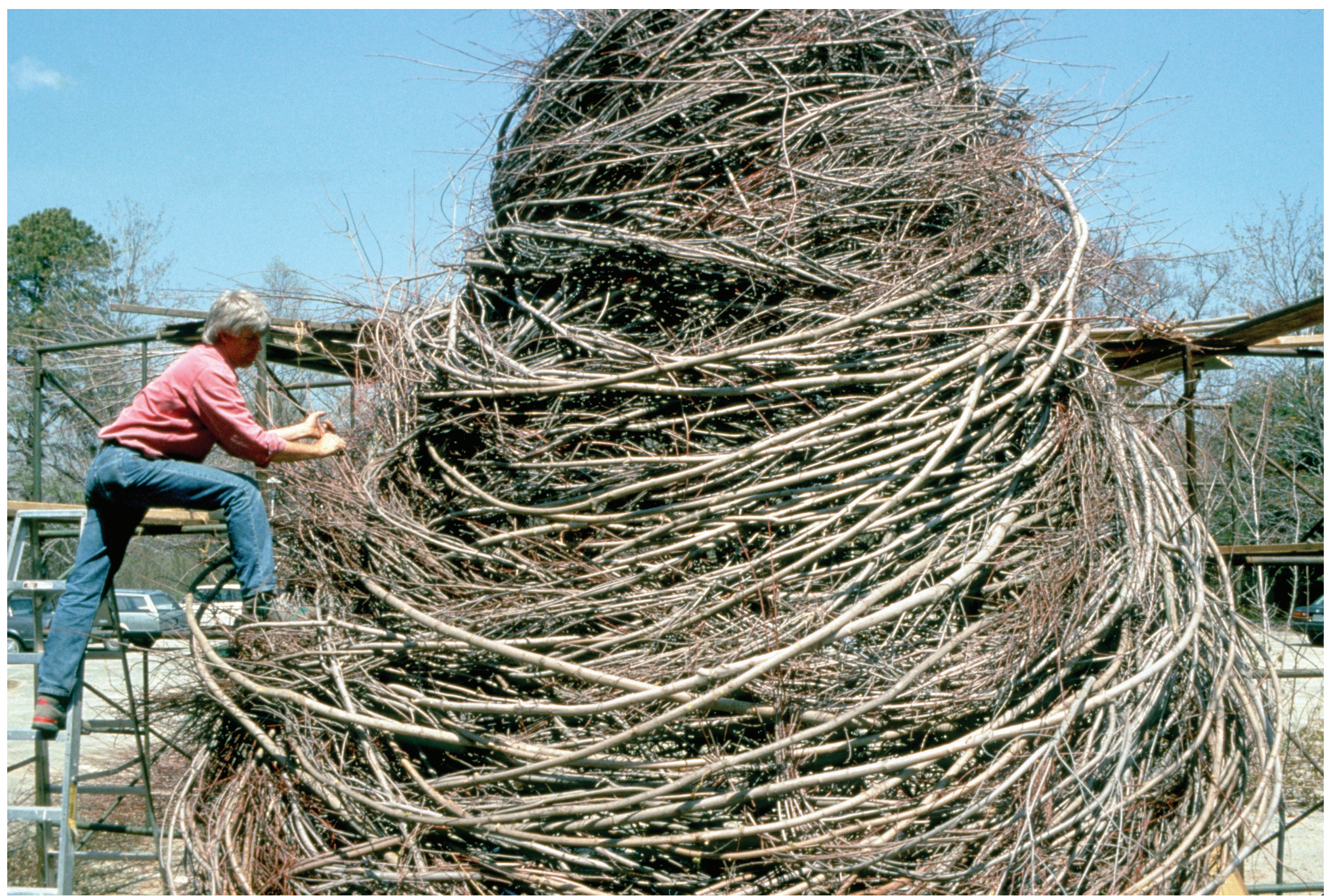

Spinoffs (1990) DeCordova Museum and Sculpture Park, Lincoln, MA. Photo: George Vasquez 
an open building site and during the three-week build, the public often speaks its mind-sometimes its skepticism, sometimes admiration. This cultural exchange has kept my eyes open and helped the viewers to see a correspondence between sculpture and its own occupations.

The first three days of a project are gathering days. During the hubbub of sorting and bundling, I search energetically for an idea that has resonance with the site and an appeal for the specific population that will encounter it. In this process, I try to remember my first feelings about the chosen site. I doodle. I have odd thoughts and might ask myself, "What would it be like to enlarge a small potted plant into a life-sized room?" I write random words down that make no sense, and then try to discover my motive. I find this kind of positive stress helps open the door to the subconscious mind; and in these situations, I become a highly aware problem solver and the world seems extra-bright. Ultimately an image and a rationale swim to the surface and I begin planning the execution. The initial blush is tentative. Maturing an idea within a specific site requires time and the opportunity to take the full measure of the space and to craft one's reactions into a workable physical object.

Essentially I have used three categories of design. First, I have built sculptures which contrast ancient ways of working with contemporary architecture as in this early work, entitled Spinoffs at the deCordova Museum in Lincoln, Massachusetts. In this work I imagined the tower of a castle falling back to its form of origin as a serf's hut. Secondly, some of my sculptures have used trees as a foil. This is clear in a work from 2000 at Swarthmore College entitled Abracadabra. This sculpture suggests a balancing act and the predominance

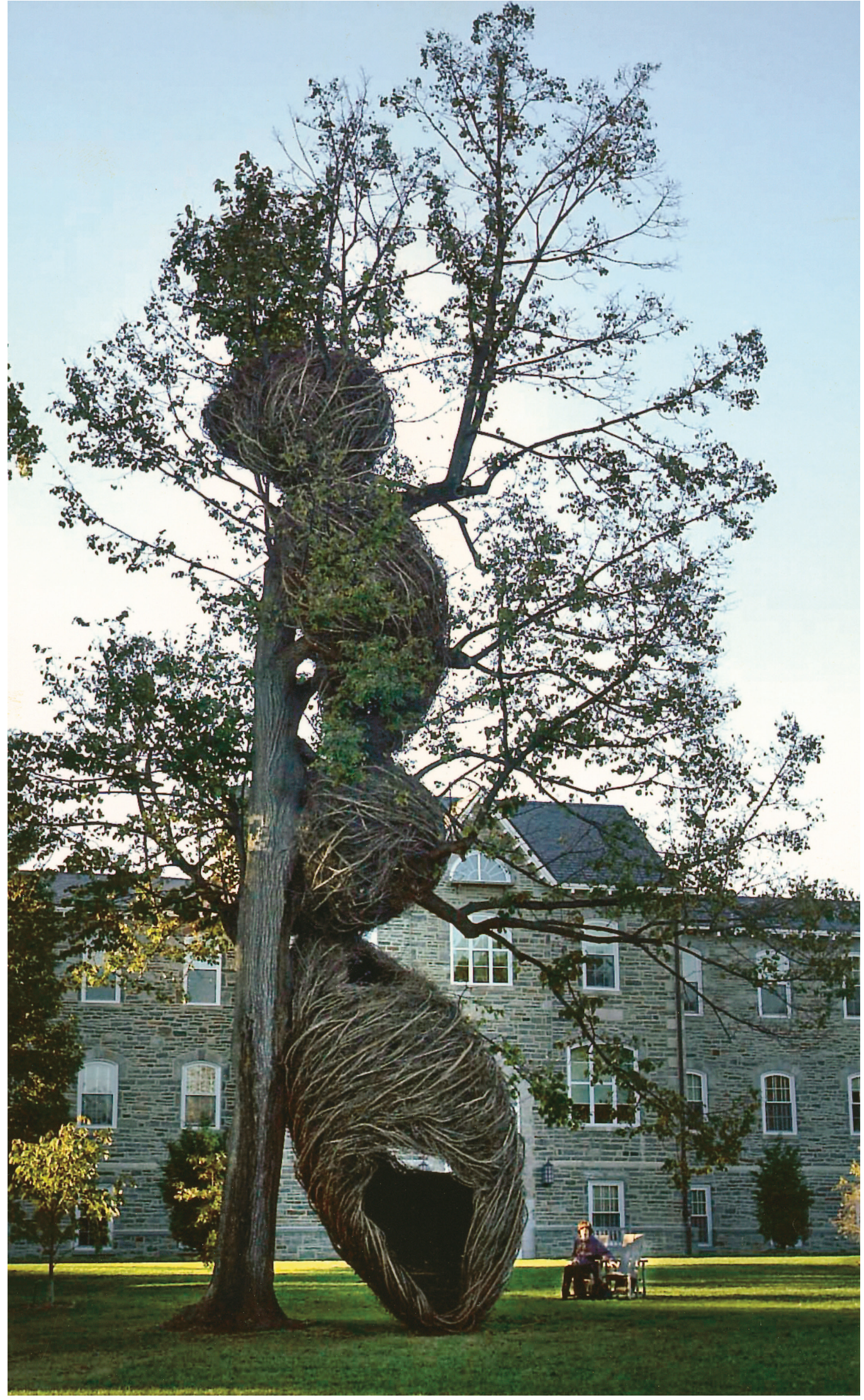

Abracadabra (2000), Swarthmore College/Scott Arboretum, Swarthmore, Pennsylvania. Photo: Diane Mattis 


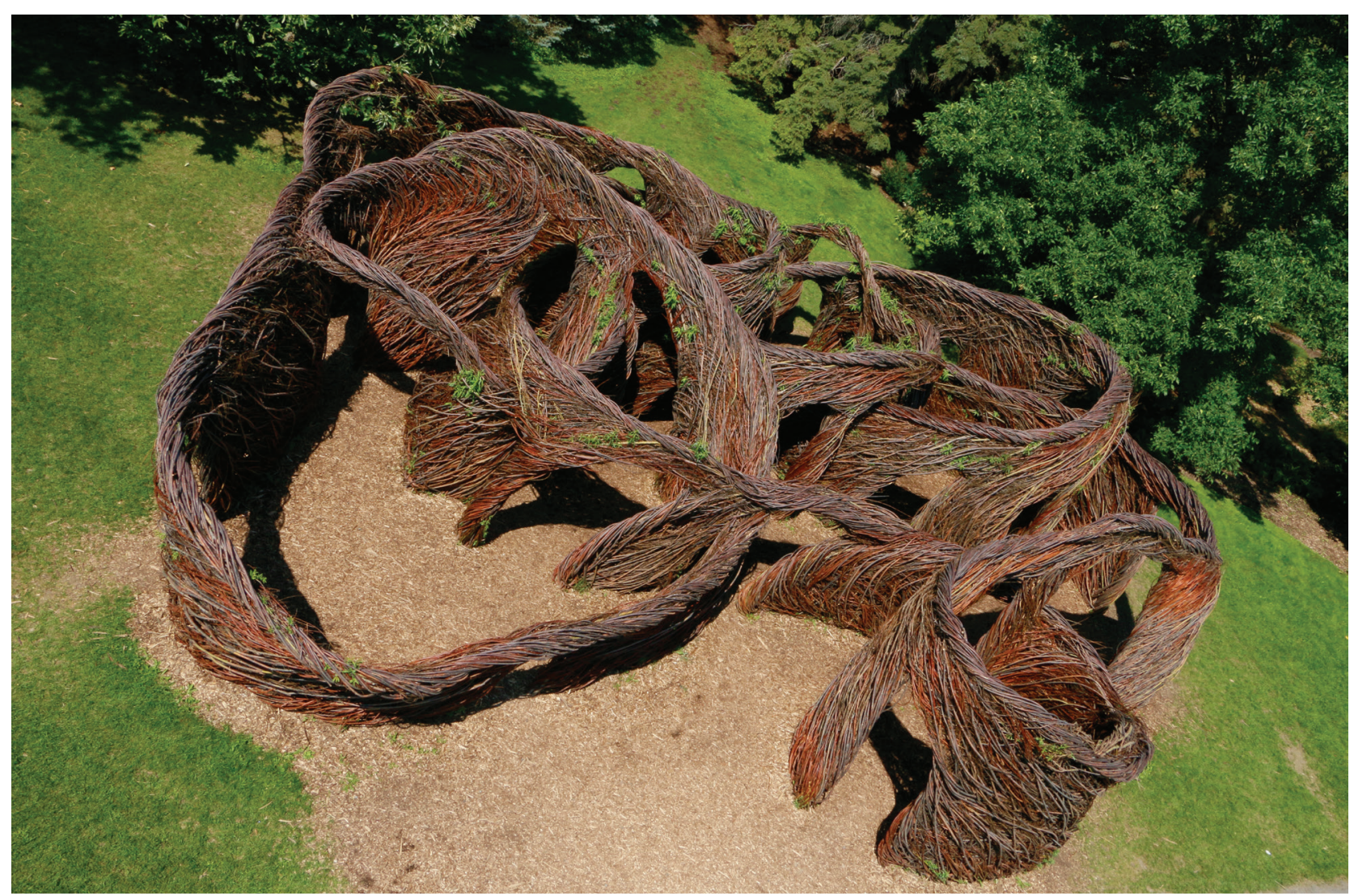

Thrown For a Loop (2017), Montreal Botanical Garden, Montreal, Quebec, Canada. Photo: Lise Servant

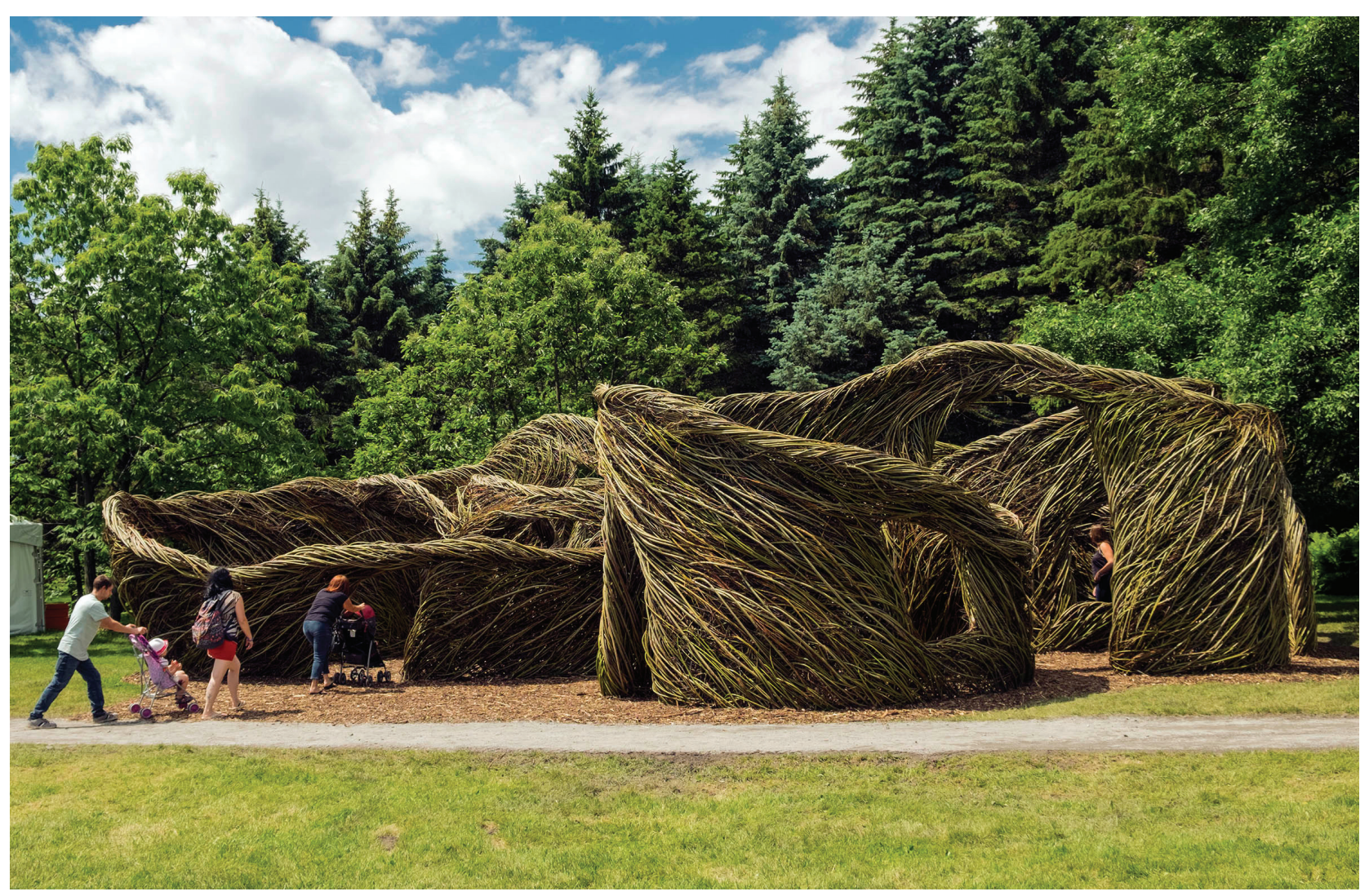

Thrown For a Loop (2017), Montreal Botanical Garden, Montreal, Quebec, Canada. Photo: Jacques Lebleu 


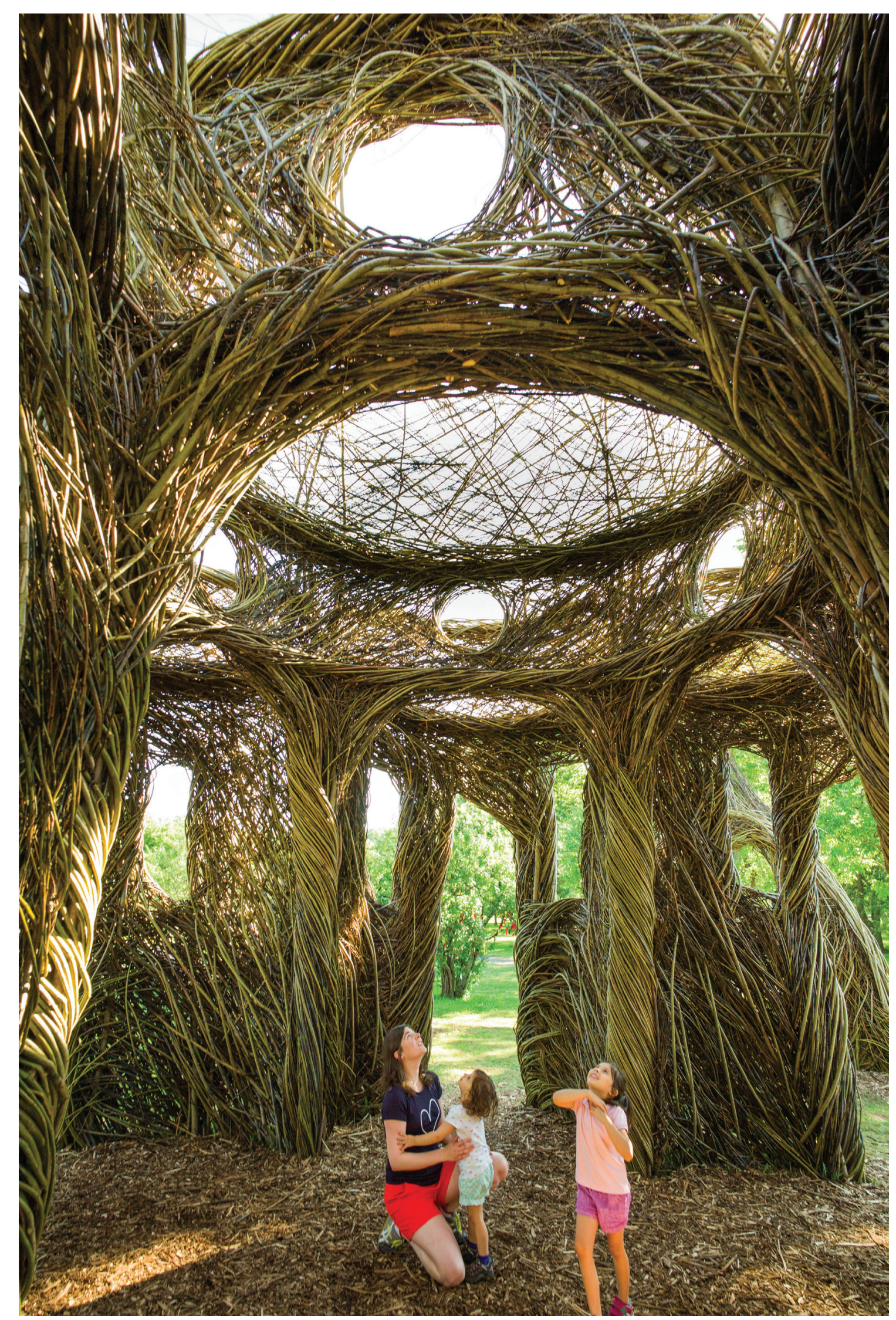




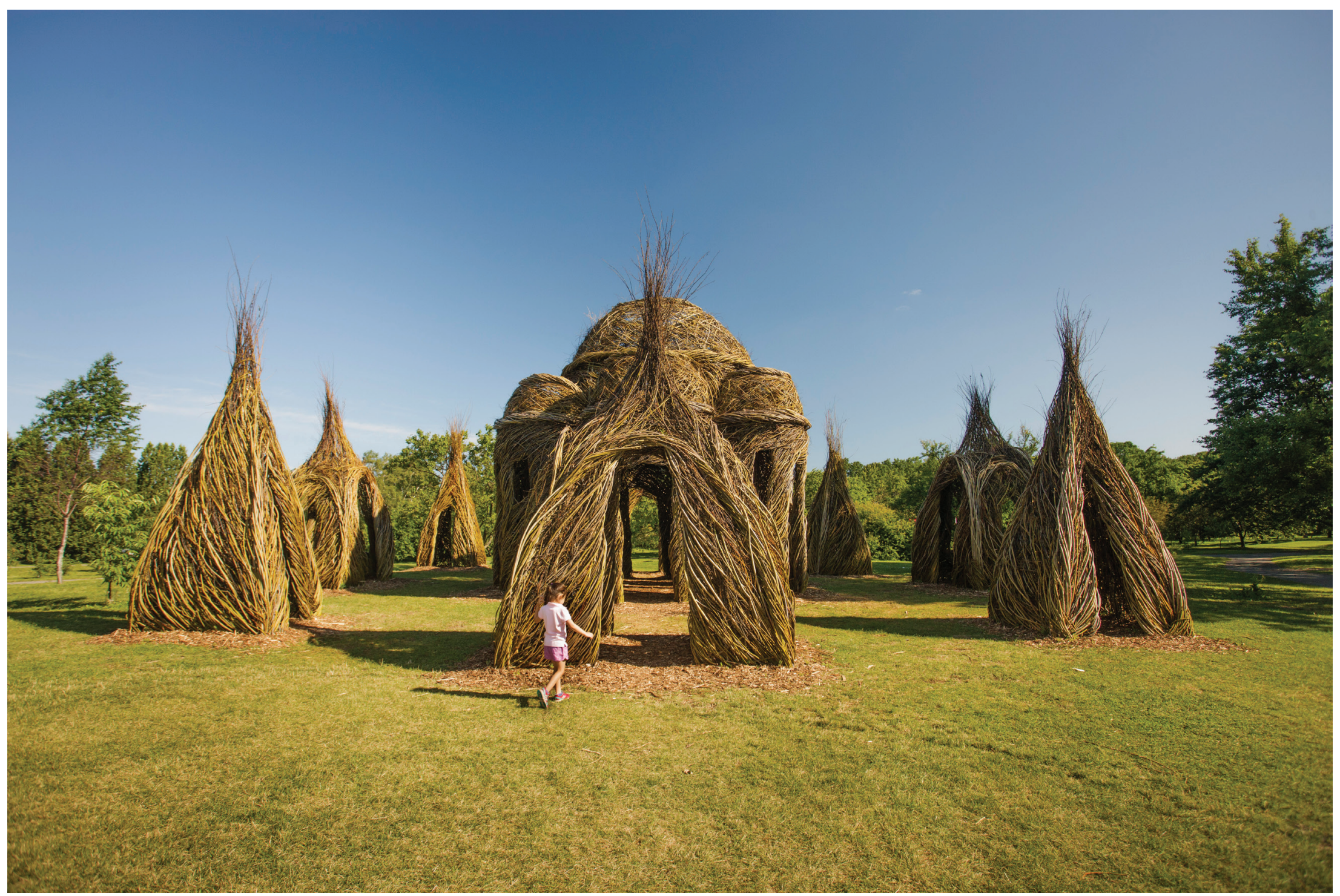

Fancy's Bower (2017), Montreal Botanical Garden, Montreal, Quebec, Canada. Photo: Pierre Charbonneau

lowed me to contrast a strong vertical with the illusion of stacked objects. Sometimes there is no possibility of entanglement with architecture or intertwining with trees, and a work must stand alone and support itself. Two recent examples at the Montreal Botanical Garden in Canada were placed in open sites. The first, Thrown for a Loop, is a sprawling, maze-like sculpture with 13 rooms and multiple doors and windows. The second, Fancy's Bower, is designed as an architectural folly inspired by the Coleridge poem "Kubla Khan" and its "stately pleasure-dome."

Overall, my years as a sculptor have been pure pleasure and have encompassed a wide range of great opportunities. Mine is work that has correspondence in architecture, in basket making, and even ikebana traditions. It flirts with indigenous building techniques and the random structures built by children. It draws inspiration from birds that construct their own apartment buildings and apes that make simple nests. Viewers' reactions to the work over the years have convinced me that many people have a nascent dream which includes a forest path, a rudimentary shelter, and a desire to commune with our fellow animals. 